\title{
ADDITION IN THE TRANSLATION OF JAMES DASHNER'S THE SCORCH TRIALS INTO INDONESIAN MEIDYNA ARRISANDI'S THE SCORCH TRIALS
}

\author{
Rizky Maisyarah \\ English Department of UNIKOM \\ rizkymaisarah@gmail.com
}

\begin{abstract}
Addition is one of translation strategies in Structural Shift that is aimed to maintain the original meaning from source language into target language. This research studied about Addition in the translation of James Dashner's The Scorch Trials into Indonesian Meydina Arrisandi's The Scorch Trials. The Scorch Trials novel was chosen because the Addition frequently found in its translation version. Addition is determined based on the explicit structure found in the target language and it is being analysed using componential analysis and propositional analysis through semantics viewpoint. Additionally, through pragmatics viewpoint, implicature, context analysis, and deixis analysis through are used in the analysis. There are 124 data found from the novel; and from those data, 1datum is full equivalent, 1 datum is partial equivalent, and 1 datum is no equivalent presented in the paper as representation.. This research is aimed to identify how addition is used in the translation process, and it was found that addition is especially used to make clear the implicit meaning from the source language or to maintain the similar meaning.
\end{abstract}

Keywords: Addition, Structural Shift, The Scorch Trials.

\section{Abstrak}

Addition adalah salah satu strategi penerjemahan dalam Structural Shift dengan tujuan untuk mempertahankan makna yang sama dari bahasa sumber ke bahasa target. Penelitian ini meneliti tentang penggunaan Addition pada novel yang berjudul The Scorch Trials karya James Dashner yang diterjemahkan oleh Meidyna Arrisandi ke dalam Bahasa Indonesia dengan judul yang sama. The Scorch Trials dipilih karena banyak data Addition yang ditemukan pada novel ini. Data yang merupakan data Addition adalah terlihatnya penambahan struktur secara eksplisit pada bahasa target. Data ini kemudian dianalisis melalui semantik dengan menggunakan leksikal dan proposisi, dan sudut pandang pragmatik melalui implikatur, analisis konteks, dan analisis deiksis. Terdapat 124 data 
Addition pada novel; satu data full equivalent, satu data partial equivalent, dan satu data no equivalent ditampilkan di artikel ini sebagai representasi data.;,. Penelitian ini bertujuan untuk mengidentifikasi bagaimana Addition digunakan di dalam penerjemahan. Penelitian menemukan bahwa Addition digunakan untuk memperjelas makna dari bahasa sumber agar tetap berada pada makna semestinya di dalam bahasa target ketika diterjemahkan.

Kata kunci: Addition, Structural Shift, The Scorch Trials.

\section{Introduction}

Translation is considered as a platform for communication between people of different cultures. As an applied language science, translation applies linguistic principles, including semantics, pragmatics, morphology, and syntax, in order to gain equivalent meaning in the target language. There are many strategies that can be applied in translation; one of them is translation shift, which is defined as the transposition of form between source language and target language. There are two major types of translation shift: level shift and category shift. Level shift is the transposition between grammar and lexis and vice versa while category shift consists of inter-system shift, unit shift, class shift, and structural shift (Catford, 1965:73). This study explores addition as one of the strategies in structural shift in order to maintain the meaning from the source language.

Structural shift, according to Catford (1965: 77), relates to the shift of structure that may occur in all ranks. In this study, a limitation is applied to discussing the shifts that occur in the clause rank. Here, the structure refers to word(s), phrase(s), and clause(s).Thus, the structural shift means that an SL language structure has different equivalent structure in TL language. The addition strategy used in this shift includes an addition or more than one addition element, word(s), phrase(s), or clause(s), in the target language structure.

Some previous studies have been performed on structural shift and translation strategies. The first study discussing structural shift is a study performed by Martina Sari Prihastanti entitled "An Analysis of Structure Shifts in The English - Bahasa Indonesia of L. Frank Baum's The Marvelous Land of $\mathrm{Oz}^{\prime}$ Novel Text". The study investigated the structural shift in grammatical complexity change, voice shift, and the impact of those shifts in meaning equivalence. The second research is from Yogi Albastian entitled "Language Compression and Omission in Saving Private Ryan Film and Its Bahasa Indonesia Subtitle". This investigated the language compression and omission, which is the opposite to addition, in Bahasa Indonesia subtitle of Saving Private Ryan. In contrast from two studies previously mentioned, this current study investigates structural shift in the form of addition from the pragmatics, meaning the context, and semantics, or 
otherwise referred to as meaning perspectives. The pragmatic elements investigated in this study are limited to deixis, implicature, and presupposition while the semantic elements explored are limited to lexical meaning and lexical components of words.

The Scorch Trials, a novel, is selected for this analysis. It is one of James Dashner's popular works in science fiction genre. This is the second part of The Maze Runner series. Due to the complexity of the sentences in the novel, such as the difficulties to find the equivalent translation in Bahasa Indonesia, addition in structural shift is frequently found in its translated Indonesian version.

\section{Data Source}

The Scorch Trials novel is chosen because it is one of James Dashner's popular works in the science fiction genre, and there are structural shifts in the form of addition phenomena found in the Bahasa Indonesia translation version. The Scorch Trials is a second book from four of The Maze Runner series, it is published in 2010 and the Indonesia translation is translated by Meidyna Arrisandi which is published in 2012.

\section{Method}

From the data source, the data are then collected through the following procedures:

first, each sentence in the source language and in the target language was compared based on its structure. If there is an element or more added in the sentence, both sentences in SL and TL are determined as an addition datum. The element here refers to word, phrase, and clause. After being determined as an addition datum, then the datum is analyzed using semantics viewpoint through proposition and lexical items and pragmatics viewpoint through deixis, implicature, and presupposition. The datum is determined as no equivalent if the meaning is not equivalent semantically and pragmatically. On the other way, the datum is determined as a full equivalent datum if the meaning is equivalent semantically and pragmatically. To determine the datum is full equivalent semantically, the TL datum must be fulfilled SL datum meaning component and SL datum proposition. To determine the datum is full equivalent pragmatically, TL datum must be fulfilled SL datum implicature, SL datum presupposition, and SL datum deixis. Adiitionally, the datum is categorized as a partial equivalent datum if the meaning is equivalent in semantics but not equivalent in pragmatics, or if the meaning is equivalent in pragmatics but not equivalent in semantics.

After categorizing the data based on meaning equivalent, each of the category (full equivalent, partial equivalent, and no equivalent) is calculated to see the most frequent additions used and then the conclusion is made. 


\section{Theoretical Review}

This research used several theories to analyze the data. The data found is analysed using the Structural Shift theory by Catford (1965: 77) as grand theory, supported by Larson in Semantics (1988) and Yule in Pragmatics (1996) as supporting theories. Catford proposes that translation shift as "transposition between an SL item to a TL item in grammatical terms". There are two major types of shifts, the first is level shift, and the second type is category shift. Level shift is transposition between levels, which an SL item has different level in TL item in the terms of grammatical and equivalent. The example of this shift is between grammar and lexis and vice versa. However, the category shifts consist of several subtypes of shift. They are class shift, unit shift, intra-system shift, and structural shift.

Class shift means that an SL item different has a translation equivalent that different in class. Meanwhile, unit shift is the shift between unit and rank. Intrasystem shift is the system between systems. Here the system definition is related to the system belongs to the language, for example, English has numeral system that may different from another language such as numeral system in Arabic language. Structural shift is the shift in structure and they can occur at all ranks. Structural shifts may be in addition form, when there is an element or more added in the target language structure, omission form, when there is an element or more omitted or eliminated in the target language structure, transposition form, when there is a different order of structure in the target language, etc.

This study explores the structural shift using addition strategy. Addition is a technique in translation that relates to the adding some elements in a TL item, as compensation of elements implicitly present in the source text. Addition as translation strategy also deals with meaning addition, as stated by Schjoldger (in Holst, 2010: 9). This added meaning unit, as stated by Van Dijk (in Sharma, 2015: $5)$, has functions to provide further information about previous events, context, or historical background, and thus have the function of explanation and embedding. Furthermore, Newmark (1988: 91) said that this addition is "normally cultural (accounting for difference between SL and TL culture), technical (relating to the topic), or linguistic (explaining wayward use of words), and is dependent on the requirement of his, as opposed to the original, readership".

Addition will affect the meaning equivalence in target text, since the translations purpose is not only transferring the structure and literal text, but also transfer the meaning and style. Meaning equivalence, as Vinay and Darbelnet stated (in Munday, 2001: 58), refers to the texts (SL and TL) which describes similar situation but different in style or structure. 


\section{Findings and Discussion}

\section{Datum 1: Full Equivalent Data}

\begin{tabular}{|l|l|}
\hline Source Language & Target Language \\
\hline $\begin{array}{l}\text { There was Frypan, pointing out a } \\
\text { window, his face pale. }\end{array}$ & $\begin{array}{l}\text { Frypan terlihat seperti menunjuk ke } \\
\text { arah jendela dengan wajah pucat. }\end{array}$ \\
\hline
\end{tabular}

\section{Analysis}

POINTING (SOMETHING) OUT $\{$ VP $\}$

1. (action) [can be seen by another participant(s)] [direct someone's gaze or attention toward something, especially by extending one's finger.]

According to componential analysis of POINT (SOMETHING) OUT above, its meaning component is [action], and an action implies that someone who also presents in the context also see what kind of action is it, and that the action is extending one's finger to direct someone's gaze or attention toward something, and in this datum Frypan extending his finger toward a window. If If it is translated in Bahasa Indonesia, the word may be translated as menunjuk.

\section{Datum 2: Partial Equivalent Data}

\begin{tabular}{|l|l|}
\hline Source Language & Target Language \\
\hline Achingly, Thomas realized he didn't & Dengan tubuhnya yang sakit Thomas \\
even know most of the names of the & sadar dia bahkan tidak tahu nama dari \\
twenty boys who'd survived the Maze, & dua puluh anak lelaki yang berhasil \\
an odd thought to have in the middle of & bertahan dari Maze--pikiran ganjil di \\
all that chaos & tengah-tengah kekacauan semacam itu. \\
\hline
\end{tabular}

\section{Analysis}

The data has an addition, tubuhnya, and this will be analyzed using deixis analysis through pragmatics viewpoint.

\section{a. Pragmatic Analysis}

The data is a referring expression from what is written in the text: 
Wake up! he yelled at himself. Wake up!

Then something disappeared from inside him. There one instant, gone the next.

He felt as if a major organ had just been ripped from his body.

It had been her. She was gone.

Achingly here implies that the ache was in his inside or his feeling, and it was not his body which hurt as the target language says. It happened when Thomas felt like he lost Teresa when Teresa gone after they were being saved to the dorm from the maze. Teresa went and joined the group $B$ as WICKED instructed her to do it, and somehow Thomas could feel her presence was no longer in the dorm so he felt like an organ ripped from his body. This analysis shows that the data is a partial equivalent data.

\section{Datum 3: No Equivalent Data}

\begin{tabular}{|l|l|}
\hline Source Language & Target Language \\
\hline $\begin{array}{l}\text { Pass out, he urged himself. Please pass } \\
\text { out, make it go away. }\end{array}$ & 'Pingsan', dia mendorong dirinya \\
& $\begin{array}{l}\text { sendiri. 'Ayolah, jangan pingsan. } \\
\text { Tetaplah sadar'. }\end{array}$ \\
\hline
\end{tabular}

\section{Analysis}

The data has two additions, the word jangan and tetaplah sadar and these will be analyzed using propositional analysis through semantics viewpoint and context analysis through pragmatics.

\section{a. Semantic Analysis}

Pass out, he urged himself. Please pass out, make it (the pain) go away.

This proposition implies that Thomas wanted to pass out but the translation version has different meaning as "ayolah, jangan pingsan, tetaplah sadar". From the proposition above, there is nothing indicates a negation. But the target language adds "jangan" or in English, it can be translated as "don't", which is contradictive to the data source. The further analysis will be explained in the pragmatic analysis.

\section{b. Pragmatic Analysis}

1. Who is speaking? Thomas. 
2. Who is being addressed? Himself.

3. When does the interaction take place? When he was just being shot and feel its pain.

4. Where does the interaction take place? Where they were in the city.

5. What is being discussed? How he wished for passing out in order to make the pain go away.

6. What is already known to speaker and listener?-

Based on the context above, Thomas wants to pass out since he felt hurt in his shoulder after being shot. These utterances imply that Thomas wanted to pass out in order to make the pain of being shot go away. Based on these analyses, this data is a not equivalent data since both of source language and the target language has different meaning.

\section{Conclusion}

The conclusions of this research are as follows:

1. This paper and the data analysis that are presented here are taken from skripsi entitled 'Addition in The Translation of James Dashner The Scorch Trials Into Indonesian Meidyna Arrisandi The Scorch Trials'. According to the skripsi, the additions used in the translation of James Dashner's "The Scorch Trials" into Indonesian take the form of words, which consists of pronoun, noun, verb, adjective, adverb, and conjunction; phrases, which consists of verb phrase, and adjective phrase; and clauses. Meanwhile, the data analyses that are presented in this paper consists of 1 full equivalent datum, 1 partial equivalent datum, and 1 no equivalent datum. The full equivalent datum is succeed maintain the same meaning because the addition here is functioned as an additional information of someone's action that can be referred through the meaning component analysis. The partial equivalent datum is using an addition which is functioned as referring expression, but due to the distance of referred expression, the translator may confused to distinguish between the referred expression from the context and the idiom, he felt as an organ ripped from his body, in the datum 2. The no equivalent datum, SL Datum 3, is using an addition as negation when the SL Datum 3 has no addition at all. According to skripsi findings, there is 1 no equivalent datum from all the data found (total data are 124 data) and this shows that addition is effective to maintain equivalent meaning in the target language.

2. In terms of the effect of additions on the translation, both from the meaning and context perspectives, the additions in the translation of English to Indonesian, particularly in the translation of James Dashner's "The Scorch 
Trials" into Indonesian, have created three equivalent categories: full equivalent, partial equivalent, and no equivalent.

3. Equivalent translation is a result of the proper use of a combination of semantic and pragmatic analyses during the translation procedure. Partial equivalents are resulted when the translation is only semantically equivalent but not pragmatically equivalent, or vice versa; or, when pragmatic analysis is not necessary to understand the meaning in the source language, it is semantically not equivalent due to a missing lexical item.

\section{References}

Bell, R. T. 1991. Translation and Translating: Theory and Practice. London/New York: Longman.

Berry, Roger. 2012. English Grammar. A resource book for students. Oxford: Routledge.

Catford, J. C. 1965. A Linguistic Theory of Translation: An Essay in Applied Linguistics. Oxford: Oxford University Press.

Chaer, Abdul. 1993. Gramatika Bahasa Indonesia. Jakarta: Rineka Cipta.

------ 2013. Pengantar Semantik Bahasa Indonesia. Jakarta: Rineka Cipta.

Cruse, D. A. 2000. Meaning in Language: An Introduction to Semantics and Pragmatics. Oxford: Oxford University Press.

Dashner, James. 2009. The Scorch Trials. New York: Delacorte Press Books United States.

2009. The Scorch Trials. Trans. Meidyna Arrisandi. Yogyakarta: Penerbit Mizan Fantasi.

Eastwood, John. 2008. Oxford Learner Pocket Grammar. Oxford: Oxford University Press.

Echols, John M. and Hassan Shadily. 1976. Kamus Inggris-Indonesia: An EnglishIndonesia Dictionary. Jakarta: Gramedia Pustaka Utama

Kreidler, C. W. 1998. Introducing English Semantics. London: Routledge.

Larson, Mildred L. 1998. Meaning-Based Translation: A Guide to Cross-Language Equivalence. Boston: University of America.

Munday, Jeremy. 2001. Introducing Translation Studies. London: Routledge.

Newmark, Peter. 1988. A Textbook of Translation. Hertfordshire: Prentice Hall.

Nida, Eugene and Charles R. Taber. 1969. The Theory and Practice of Translation. Leiden: E. J. Brill.

Saeed, J. I. 2009. Semantics (3 ${ }^{\text {rd }}$ Edition). Oxford: Blackwell.

Yule, George. 1996. Pragmatics (Oxford Introduction to Language Study). Oxford:

Oxford University Press. 